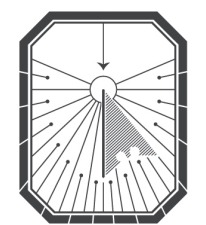

KYIV-MOHYLA

LAW \& POLITICS JOURNAL

KYIV-MOHYLA SCHOLARLY PEER-REVIEWED JOURNALS

Illegal Crossing of the State Border in Light of Polish Criminal Law

Author(s): Katarzyna Banasik

Source: Kyiv-Mohyla Law and Politics Journal 2 (2016): 189-201

Published by: National University of Kyiv-Mohyla Academy

http://kmlpj.ukma.edu.ua/ 


\title{
Illegal Crossing of the State Border in Light of Polish Criminal Law
}

\author{
Katarzyna Banasik \\ Andrzej Frycz Modrzewski Krakow University, \\ Faculty of Law, Administration and International Relations
}

\begin{abstract}
The subject of this paper is the illegal crossing of the Polish border. The paper focuses on criminal law issues. To explain the element "in violation of the relevant regulations," being one of the elements of the criminal offences regarding the illegal crossing of the state border, the author begins by presenting the significant regulations of the Schengen Borders Code and of the Polish statute on the protection of the state border. The author then makes a detailed analysis of offences concerning the unlawful crossing of the Polish border. The statute of limitations on punishability and provisions for the rehabilitation of offenders convicted of the illegal crossing of the Polish border are also the subject of the analysis. The author concludes by making the evaluation of Polish criminal law regulations on the illegal crossing of the state border.
\end{abstract}

Key Words: Schengen Borders Code, internal borders, external borders, unlawful crossing of the state border, penalization of illegal crossing the Polish border, statute of limitations, rehabilitation of offender.

\section{(2)}

The subject of this paper is the illegal crossing of the state border in light of Polish criminal law. The author focuses on the analysis of offences concerning the unlawful crossing of the state border. However, bearing in mind the element of offences "in violation of the relevant regulations," the author begins by explaining when the crossing of the state border is authorized. Therefore, the author presents the relevant regulations of the Schengen Borders Code and then those of the Polish statute on the protection of the state border.

Since Poland's accession to the Schengen area on 21 December 2007, the Schengen Borders Code is the most significant legal act in the aspect of crossing and protecting Polish state borders. The Schengen Borders Code is a Community Code on the rules governing the movement of persons across borders. It is a regulation of the European Parliament and of the Council of 15 March 2006. ${ }^{2}$ In accordance with the Code, Poland has two types of borders:

“Polska w strefie Schengen," accessed December 17, 2016, http://www.kair.msz.gov.pl/pl/informacje_ konsularne/polska_w_schengen/.

2

"The Schengen Borders Code," accessed March 15, 2016, http://eur-lex.europa.eu/legal-content/EN/

TXT/?uri=URISERV\% ${ }_{3}$ Ali4514. 
internal borders and an external border. Key and relevant regulations of the Schengen Borders Code will be presented.

The European Parliament and the Council of the European Union have emphasized in the Code that border control is in the interest not only of the Member State at whose external borders it is carried out, but of all Member States that have abolished internal border control. The aims of border control are set out in Section 6 of the Code in the following way: Border control should help combat illegal immigration and trafficking in human beings and prevent any threat to the Member States' internal security, public policy, public health, and international relations. Section 15 of the Code stipulates that the Member States should have the possibility of temporarily reintroducing border control at internal borders in the event of a serious threat to their public policy or internal security; however, the scope and duration of any temporary reintroduction border control at internal borders should be restricted to the bare minimum needed to respond to that threat.

Pursuant to Section 12 of the Code, Member States should designate the national service or services responsible for border-control tasks in accordance with their national law. In Poland, the Border Guard is the service responsible for the protection of Polish borders. Article 1, paragraph 1 of the statute on the Border Guard reads:

The Border Guard is a homogenous, uniformed, and armed formation designated to the protection of the state border, to the control of crossborder movement, and to the prevention and counteraction of illegal migration.

The tasks of the Border Guard include, among other things, the protection of the state border on the ground and on the sea, the organization and conduct of control of cross-border movement, the prevention and counteraction of illegal migration, issuing permits for crossing the state border, including visas, and recognizing, preventing and detecting criminal offences and contraventions, and prosecuting their perpetrators (Article 1, paragraph 2 of the statute on the Border Guard). ${ }^{3}$

The last task is related to offences falling into the sphere of competence of the Border Guard and comprises strict criminal offences and contraventions concerning the crossing of the state border in accordance with provisions.

The Schengen Borders Code provides for the absence of border control of persons crossing the internal borders between Member States of the European Union and establishes rules governing border control of persons crossing the external borders of the Member States of the European Union (Article 1). The Code defines some key terms in Article 2 as follows: "internal borders" means: the common land borders, including river and lake borders, of the Member States; the airports of the Member States for internal flights; sea, river and lake ports of the Member States for regular ferry connections; "external borders" means the Member States' land borders, including river and lake borders, sea borders and their airports, river ports, sea ports

3 Statute of 12 October 199 o “On the Border Guard," Dziennik Ustaw, November 19, 199o, No. 78, item 462 , with later changes. 
and lake ports, provided that they are not internal borders; "internal flight" means any flight exclusively to or from the territories of the Member States and not landing in the territory of a third country.

In accordance with Article 4, paragraph 1 of the Code, external borders may be crossed only at border crossing points and during the fixed opening hours. However, paragraph 2 provides for some exceptions to this obligation. It is relevant to the subject matter of this paper that Article 4, paragraph 3 of the Code states that the Member States shall introduce penalties, in accordance with their national law, for the unauthorized crossing of external borders at places other than border crossing points or at times other than the fixed opening hours. These penalties shall be effective, proportionate and dissuasive.

Article 5 of the Code sets out the entry conditions for third-country nationals as follows: For stays not exceeding three months per six-month period, the entry conditions for thirdcountry nationals shall be the following: (1) they are in possession of a valid travel document or documents authorizing them to cross the border; (2) they are in possession of a valid visa, if required pursuant to Council Regulation (EC) No 539/2001 of 15 March 2001 listing the third countries whose nationals must be in possession of visas when crossing the external borders and those whose nationals are exempt from that requirement, except where they hold a valid residence permit; (3) they justify the purpose and conditions of the intended stay, and they have sufficient means of subsistence, both for the duration of the intended stay and for the return to their country of origin or transit to a third country into which they are certain to be admitted, or are in a position to acquire such means lawfully; (4) they are not persons for whom an alert has been issued in the SIS for the purposes of refusing entry; and (5) they are not considered to be a threat to public policy, internal security, public health or the international relations of any of the Member States, in particular where no alert has been issued in Member States' national data bases for the purposes of refusing entry on the same grounds. The above-mentioned requirement imposing the necessity to be in possession of a valid visa applies, among others, to the nationals of Ukraine (according to Article 1 of Council Regulation (EC) No. 539/2001).4 The detailed rules on conducting external border checks on persons are set out in Article 6 and 7 of the Code. It is stated that on entry and exit, third-country nationals shall be subject to thorough checks.

External border surveillance is regulated in Article 12 of the Code. The main purpose of border surveillance shall be to prevent unauthorized border crossings, to counter cross-border criminality and to take measures against persons who have crossed the border illegally. The border guards shall use stationary or mobile units to carry out border surveillance. That surveillance shall be carried out in such a way as to prevent and discourage persons from circumventing the checks at border crossing points. Surveillance between border crossing points shall be carried out by border guards whose numbers and methods shall be adapted to existing or foreseen risks and threats. It shall involve frequent and sudden changes to surveillance periods, so that unauthorized border crossings are always at risk of being detected. Surveillance shall be

4 Council Regulation (EC) No. 539/2001 of 15 March 2001 listing the third countries whose nationals must be in possession of visas when crossing the external borders and those whose nationals are exempt from that requirement, accessed March 16, 2016, http://eur-lex.europa.eu/legal-content/EN/ ALL/?uri=celex\%3A32001Ro539. 
carried out by stationary or mobile units which perform their duties by patrolling or stationing themselves at places known or perceived to be sensitive, the aim of such surveillance being to apprehend individuals crossing the border illegally. Surveillance may also be carried out by technical means, including electronic means.

Article 20 of the Code provides for the abolition of border control at internal borders. Internal borders may be crossed at any point without a border check on persons, irrespective of their nationality, being carried out. However, according to Article 21, the abolition of border control at internal borders shall not affect: (1) the exercise of police powers by the competent authorities of the Member States under national law, insofar as the exercise of those powers does not have an effect equivalent to border checks; (2) security checks on persons carried out at ports and airports by the competent authorities under the law of each Member State, by port or airport officials or carriers, provided that such checks are also carried out on persons travelling within a Member State; (3) the possibility for a Member State to provide by law for an obligation to hold or carry papers and documents; and (4) the obligation on thirdcountry nationals to report their presence on the territory of any Member State pursuant to the provisions of Article 22 of the Schengen Convention. It is worth mentioning that Article 23 of the Schengen Borders Code allows to temporarily reintroduce border control at internal borders. Where there is a serious threat to public policy or internal security, a Member State may exceptionally reintroduce border control at its internal borders for a limited period of no more than 30 days or for the foreseeable duration of the serious threat if its duration exceeds the period of 30 days (under conditions set out in paragraph 2, the Member State may prolong border control). The scope and duration of the temporary reintroduction of border control at internal borders shall not exceed what is strictly necessary to respond to the serious threat.

For the mutual relations between Poland and Ukraine, Article 35 of the Code is significant. According to this provision, the Schengen Borders Code shall be without prejudice to Community rules on local border traffic and to existing bilateral agreements on local border traffic.

The eastern border of Poland is the external border in the meaning of the Schengen Borders Code and the eastern border of the European Union. The Polish border, referred to as an external border, has a length of $1580,77 \mathrm{~km} .{ }^{5}$ This is the border with the Russian Federation, the Republic of Belarus and Ukraine. The Polish border with the Federal Republic of Germany, the Czech Republic, the Slovak Republic, and the Republic of Lithuania is the internal border in the meaning of the Schengen Borders Code and it is 1930,62 km long. ${ }^{6}$

The Polish-Ukrainian border is a land border and it is 535,18 km long. ${ }^{7}$ Article 2 of the Polish statute on the protection of the state border stipulates that the delineation of the state border with neighboring states is set out in international agreements made by the Republic of Poland. The relevant agreement with Ukraine was made on 12 January 1993 in Kyiv. ${ }^{8}$

5 “Granice RP," April 23, 2008, accessed March 19, 2016, https://www.strazgraniczna.pl/pl/granica/ granice-rp/1910, Granice-RP.html.

6 "Granice RP."

7 “Granice RP."

8 Agreement between the Republic of Poland and Ukraine "On Legal Regime on the Polish-Ukrainian State Border and Cooperation and Mutual Assistance in Border Issues," Kyiv, January 12, 1993, 
The statute on the protection of the state border regulates crossing the state border in Chapter $3 .^{9}$ According to Article 14, crossing the state border is allowed on the grounds of documents authorizing to cross the border (paragraph 1). Crossing the state border being the internal border in the meaning of the Schengen Borders Code takes place with the lines described in the Schengen Borders Code (paragraph 3 ). Crossing this border is allowed at border crossing points designated and opened to cross-border movement, with taking into account international agreements binding the Republic of Poland (Article 14a). The Polish-Ukrainian border is the external border in the meaning of the Schengen Borders Code. Therefore Article 15 of the above-mentioned statute applies to crossing this border. This Article provides that persons crossing the state border being the external border in the meaning of the Schengen Borders Code are obliged to undergo border control, to the extent specified in the Schengen Borders Code and in separate provisions, carried out by the functionaries of the Border Guard.

Article 16, paragraph 1 of the statute on the protection of the state border reads: Road, railway, and river border crossing points and types of movement allowed at these crossing points are set out in international agreements. Paragraph 2 states that the Council of Ministers sets out, in a regulation, sea and permanent air border crossing points and specifies the type of movement allowed at these crossing points, taking into account, in particular, international agreements. According to paragraph 4, the minister responsible for internal affairs announces in the Official Journal of the Republic of Poland "Monitor Polski" the border crossing points, type of movement allowed at these crossing points and opening hours of these crossing points. The latest announcement was made on 3 July 2015 and published on 21 July $2015 \cdot{ }^{10}$ In an annex, it lists the border crossing points as of 25 June 2015 . There are 14 road and railway border crossing points between Poland and Ukraine. All of them are open round-the-clock.

The significance and the topicality of the problem discussed in this paper can be illustrated with the statistical data. According to the latest available data, in the period from January to June 2016 the Polish Border Guard detained 3514 persons for the illegal crossing the Polish border (or an attempt of illegal crossing). Most of them were apprehended at the border with Ukraine (1068 persons). The majority of all detained persons, together at internal and external borders, were the nationals of Ukraine (1909 persons). Most of them were of course stopped at the Ukrainian-Polish border. Russians were in second place (296 persons). The majority of Ukrainians were apprehended when entering Poland (1595 persons). 314 Ukrainians were stopped when trying to leave Polish territory. It is also worth mentioning that in the first half of 2016 the Polish Border Guard revealed 1521 cases of counterfeit documents. The majority of perpetrators were the nationals of Ukraine (1290 persons). In most cases (1015) the counterfeit document was a visa.

Dziennik Ustaw, 63 (1994), item 267.

9 Statute of 12 October 1990 "On the Protection of State Border," Dziennik Ustaw, November 19, 199o, No. 78 , item 461 , with later changes.

10 Announcement of the Interior Minister of 3 July 2015 "On the Border Crossing points, Type of Movement Allowed at these Crossing Points and Opening Hours of these Crossing Points," Monitor Polski, July 21, 2015, item 636, accessed March 18, 2016, http://isip.sejm.gov.pl/ DetailsServlet?id=WMP20150000636. 
The Polish Constitution states that the Republic of Poland shall safeguard the independence and integrity of its territory (Article 5).11 This obligation is fulfilled, among others, through the protection of the Polish border and the criminalization of conduct consisting of the illegal crossing of the state border. In Polish criminal law, there are three offences relating to illegal crossing of the Polish border. One of them is a contravention (i.e. summary offence; criminal offence sensu largo) and is described in the Code of Contraventions. Two of them are strict criminal offences (i.e. criminal offences sensu stricto) and are penalized in the Penal Code. The legal interests protected by the relevant provisions of both Codes are the inviolability of the state border, the public order in the aspect of cross-border movement, and the security of the state. ${ }^{12}$

Article 49a of the Code of Contraventions criminalizes conduct consisting of the illegal crossing of the state border. ${ }^{13}$ The provision of Article 49a, paragraph 1, reads: Whoever, in violation of the relevant regulations, crosses the border of the Republic of Poland is liable to a fine. In the literature, this conduct is called "simple" illegal crossing of the state border, to emphasize the difference in relation to the illegal crossing of the state border penalized in the Penal Code. ${ }^{14}$ The offence in question can be committed by anyone, that is by a Polish citizen or a foreigner (a citizen of another state or a stateless person). ${ }^{15}$ It can be committed either on entry into or exit from Polish territory. ${ }^{16}$ The behavior of a perpetrator consists of "crossing"

11 Statute of 2 April 1997 “The Constitution of the Republic of Poland," Dziennik Ustaw, July 16, 1997 , No. 78 , item 483 , with later changes.

12 See i.e.: Marcin Jachimowicz, "Nowe zasady odpowiedzialności za nielegalne przekroczenie granicy RP," Prokuratura i Prawo 5 (2006): 50-51; Krzysztof Wiak, “Komentarz do art. 264 k.k.," in Kodeks karny. Komentarz, eds. A. Grześkowiak and K. Wiak (Warszawa: C. H. Beck, 2015), 1223; Dagmara Gruszecka, "Komentarz do art. 264 k.k.," in Kodeks karny. Część szczególna. Komentarz, ed. J. Giezek (Warszawa: LEX a Wolters Kluwer business, 2014), 961; Wojciech Kotowski, Kodeks wykroczeń. Komentarz (Warszawa: Oficyna a Wolters Kluwer business, 2009), 39 o.

13 Statute of 20 May 1971 “The Code of Contraventions," Dziennik Ustaw, May 31, 1971, No. 12, item 114, with later changes.

14 See, for instance: Aleksander Herzog, "Komentarz do art. 264 k.k.," in Kodeks karny. Komentarz, ed. R. A. Stefański, (Warszawa: C. H. Beck, 2015), 1657; Zbigniew Ćwiąkalski, "Komentarz do art. 264 k. k.," in Kodeks karny. Część szczególna. Tom II. Komentarz do art. 117-277, ed. A. Zoll (Warszawa: LEX a Wolters Kluwer business, 2013), 1447.

15 Jachimowicz, “Nowe zasady odpowiedzialności za nielegalne przekroczenie granicy RP," 51; Marek Bojarski, "Komentarz do art. 49a k.w.," in Kodeks wykroczeń. Komentarz, eds. M. Bojarski and W. Radecki (Warszawa: C. H. Beck, 2013), 120; Tadeusz Bojarski, “Komentarz do art. 49a k.w.," in Kodeks wykroczeń. Komentarz, ed. T. Bojarski (Warszawa: Lexis Nexis, 2009), 120; Wiak, "Komentarz do art. 264 k.k.," 1223.

16 Compare: Roman Góral, Kodeks karny. Praktyczny komentarz (Warszawa: Wydawnictwo Zrzeszenia Prawników Polskich, 2007), 451; Michał Kalitowski, "Komentarz do art. 264 k.k.," in Kodeks karny. Komentarz, ed. M. Filar (Warszawa: Wolters Kluwer, 2014), 1384; Aneta Michalska-Warias, "Komentarz do art. 264 k.k., in Kodeks karny. Część szczególna. Tom II. Komentarz. Art. 222-316, eds. M. Królikowski and R. Zabłocki (Warszawa: C. H. Beck, 2013), 395; Zbigniew Mirgos, "Przestępstwo bezprawnego przekroczenia granicy państwowej PRL na tle porównawczym," Nowe Prawo 9 (198): 44. 
the border, which can happen on foot, by car, by train, by boat, by balloon, and so on. ${ }^{17}$ To be criminal, crossing has to be "in violation of the relevant regulations." The relevant regulations appear above. However, it can be stated here that crossing would be illegal, for instance, if it happened outside designated border crossing points (also known as crossing through a green border) or at a crossing point but without required documents, for example without a passport (or with a counterfeit passport) or not being in possession of a valid visa. ${ }^{18}$

As to the mental element of the offence in question, there are different opinions presented in the Polish literature. One of them is that the punishability of this offence is rational only in the case where a perpetrator acted with dolus directus or dolus eventualis. ${ }^{19}$ One commentator says that the analyzed offence can only be committed with dolus directus. ${ }^{20}$ In the view of the author of this paper, in the current state of the law a perpetrator of the analyzed contravention can act with intent (i.e. with dolus directus) or recklessly (i.e. with dolus eventualis) or can even be negligent. This is also the predominant opinion among legal scholars. ${ }^{21}$ The provision of Article 5 of the Code of Contraventions can be given as an argument. This Article sets out a rule applicable to every offence described in this Code as follows: A contravention can be committed intentionally or recklessly as well as negligently, unless a statute provides liability only for intentional or reckless contravention. The opposite argument that the word "crosses," being an element of the offence, would indicate intention or recklessness and it would exclude negligence, is not convincing. ${ }^{22}$ In conclusion, a person crossing the border by accident, for instance without noticing a border sign while losing his way or just walking through a forest as a tourist, may also be charged with this offence.

A provision of Article 49a, paragraph 2 of the Code of Contraventions, stipulating that an attempt to commit a contravention and aiding and abetting the commission of a contravention are punishable, is significant since under the law of contraventions, the rule is that an attempt is punishable only in the case where it is provided for in a statute (Article 11, paragraph 2) and that aiding and abetting is punishable only in the case where it is provided for in a statute and the perpetrator completed the elements of an offence (Article 14, paragraph 1). An attempt and aiding and abetting are prohibited under the same punishment as the perpetration of the offence (Article 11, paragraph 3 and Article 14, paragraph 3). The above-mentioned Article 49a, paragraph 2 has a great significance in practice because many cases of the illegal crossing of the Polish border are prevented by the Border Guard. If an attempt was not prohibited under

17 Jachimowicz, “Nowe zasady odpowiedzialności za nielegalne przekroczenie granicy RP," 54. Compare: Mirgos, "Przestępstwo bezprawnego przekroczenia granicy państwowej PRL na tle porównawczym," 43; Ćwiąkalski, "Komentarz do art. 264 k.k.," 1448-49; Gruszecka, “Komentarz do art. 264 k. k.," 962; Michalska-Warias, “Komentarz do art. 264 k.k.," 395.

18 Ćwiąkalski, "Komentarz do art. 264 k.k.," 1450-51.

19 Andrzej Marek, Prawo karne (Warszawa: C. H. Beck, 2011), 645.

20 Kotowski, Kodeks wykroczeń. Komentarz, 395.

21 M. Bojarski, "Komentarz do art. 49a k.w.," 398; Marek Mozgawa, "Komentarz do art. 49a k.w.," in Kodeks wykroczeń. Komentarz, ed. M. Mozgawa (Warszawa: LEX a Wolters Kluwer business, 20o9), 177; Michalska-Warias, "Komentarz do art. 264 k.k.," 400.

Jachimowicz, "Nowe zasady odpowiedzialności za nielegalne przekroczenie granicy RP," 51. 
a punishment, a person trying unsuccessfully to cross the Polish border illegally would not commit any offence and would be free from any responsibility for his illicit action.

The discussed offence is prohibited under the penalty of a fine. In accordance with Article 24, paragraph 1, a fine shall be imposed in the amount from 20 PLN to 5 , 00o PLN, unless a statute provides otherwise. In setting the fine, the court shall consider the income of the perpetrator, his personal and family situation, property relationships, and his earning capacity (paragraph 3 ).

An important issue for criminal responsibility is the statute of limitations. The offence of a person who managed to illegally cross the Polish border usually falls under the statute of limitations after one year from the date on which the border was crossed. Article 45, paragraph 1 of the Code of Contraventions provides that the punishability of a contravention ceases after the expiration of one year from the time of the commission thereof; if criminal proceedings have been commenced during this period, the punishability of a contravention ceases after the expiration of two years from the time the act was committed.

For a person being convicted of a criminal offence, the legal regulation of the institution of the rehabilitation of offenders has a great significance in his or her personal and professional life. In the case of sentencing for a contravention, however, there are actually no serious or significant consequences for the offender, other than the imposed penalty. Article 46, paragraph 1 of the Code of Contraventions states that the sentence is considered non-existent after the expiration of 2 years from the execution or remission or from the time its execution is barred by the statute of limitations. Thus, in the case of the simple illegal crossing of the Polish border, the rehabilitation period is 2 years.

The Polish Penal Code ${ }^{23}$ in Article 264, paragraph 2, states:

Whoever, in violation of the relevant regulations, crosses the border of the Republic of Poland, with the use of violence, threat or deceit or in cooperation with other persons, is liable to imprisonment for a term not exceeding 3 years.

Some elements of this criminal offence are the same as the elements of the contravention discussed above. They are to be understood in the same way and therefore there is no need to analyze them here. The material elements of this offence having conclusive significance for the qualification of a conduct as a strict criminal offence and not as a contravention are "with the use of violence," "with the use of threat," "with the use of deceit" and "in cooperation with other persons." These elements need a short explanation. The use of violence has to be present in order to cross the border. "Violence" means physical violence directed against a thing or a person. ${ }^{24}$ The use of violence can consist of employing force against devices blocking the border crossing through, for example, breaking a barbed wire fence standing on the border line or

23 Statute of 6 June 1997 “The Penal Code," Dziennik Ustaw, August 2, 1997, No. 88, item 553, with later changes.

24 Michalska-Warias, "Komentarz do art. 264 k.k.," 397; Andrzej Marek, Kodeks karny. Komentarz (Warszawa: LEX a Wolters Kluwer business, 2010), 564 . 
running over the posts blocking the way. ${ }^{25}$ Violence can also be used against an officer of the Border Guard or even a casual person trying to stop the perpetrator, for instance a forester or a tourist. ${ }^{26}$ It is obvious that the use of threat can be directed only against people. "Threat" does not need to be expressed through words. It does not matter whether the perpetrator has an actual possibility or intention to execute the threat. "Deceit" in the sense of the analyzed Article means a misleading conduct of a person crossing the border, for example, showing a border guard an original passport of another person while pretending (by imitating physical features) to be that person. ${ }^{27}$ The element of "cooperation with other persons" means that there are a minimum of three people acting in an agreement. In other words, a perpetrator crosses the border in cooperation with two or more persons. There may be a situation where all the cooperating people cross the border together or a case where only one perpetrator crosses the border and other people help him to do it. ${ }^{28}$

The second criminal offence concerning the illegal crossing of the state border is described in Article 264, paragraph 3 of the Polish Penal Code. This provision states: Whoever organizes for other persons the crossing of the border of the Republic of Poland in violation of the relevant regulations is liable to imprisonment for a term from 6 months to 8 years. The offence can be committed by anyone anywhere. The perpetrator can be a Polish citizen or a foreigner. On the contrary to the offences discussed above, the offence in question does need to be committed at the border. It can take place anywhere. ${ }^{29}$ Organizing the crossing of the border consists of, for instance, preparing a plan of the route or providing the person who wants to cross the border with things or devices facilitating crossing the border, for example with hand torches, nightvision devices, rubber dinghies or dark clothes. ${ }^{30}$ The perpetrator of the offence consisting of the organization of the crossing of the border does not need to cross the border by himself.. However, if he does, he shall be liable for the illegal crossing of the state border as well.

In the Polish literature, there is a controversy over the interpretation of the analyzed provision in the aspect of the completion of the offence. Most commentators say that the offence is completed and not only attempted when the perpetrator organized the crossing of the border for other persons only once. ${ }^{32}$ However, an opinion has been also expressed that the words "organizes the crossing" indicate that the activity of the perpetrator is not a one-time activity but a repeated activity. ${ }^{33}$ In the view of the author of this paper, the predominant stance

Ćwiąkalski, “Komentarz do art. 264 k.k.," 1451; Jachimowicz, "Nowe zasady odpowiedzialności za nielegalne przekroczenie granicy RP," 57 .

Jachimowicz, "Nowe zasady odpowiedzialności za nielegalne przekroczenie granicy RP," 6o; Ćwiąkalski, "Komentarz," 1449.

$3^{1} \quad$ Michalska-Warias, "Komentarz do art. 264 k.k.," 396. See, for instance:Jachimowicz, "Nowe zasady odpowiedzialności za nielegalne przekroczenie granicy RP," 61; Michalska-Warias, “Komentarz do art. 264 k.k.," 395-96. 
is right. Moreover, it should be stressed that the provision clearly speaks about "other persons" (plural) and not "other person." The perpetrator of the offence in question organizes the illegal crossing of the Polish border for a minimum of two people.

The criminalization of the organization of the unlawful crossing of the Polish border for other persons is directed mainly against smugglers of foreigners who try to bring people to Poland or to transfer them through Poland to western Europe. ${ }^{34}$ The penalization of this activity has a great significance today, when many economic migrants want to get to countries of the European Union.

The mental element (mens rea) of both offences criminalized in Article 264 of the Penal Code consists of intention. They can only be committed with dolus directus ${ }^{35}$ since it is not possible to organize something or to use, for example, violence with dolus eventualis. Negligence is obviously excluded.

On the grounds of the provisions in the General Part of the Polish Penal Code (Article 13, paragraph 1; Article 18, paragraph 3), an attempt to commit both criminal offences as well as aiding and abetting the commission of both criminal offences are punishable. According to Article 14, paragraph 1, the court shall impose the penalty for an attempt within the limits of the penalty provided for the given offence. According to Article 19, paragraph 1, the court shall impose the penalty for instigation and aiding and abetting within the limits of the sanction provided in law for perpetration. However, in imposing the penalty for aiding and abetting, the court may apply extraordinary mitigation of punishment (Article 19, paragraph 2 of the Penal Code).

The Penal Code provides for the punishment of imprisonment for both criminal offences. The limits of the penalty for the offence described in paragraph 3 of Article 264 are expressly given in this provision (from 6 months to 8 years). Paragraph 2 of Article 264 provides only for the maximum of the penalty which is 3 years. As to the minimum of this penalty, the general regulation applies. According to Article 37 of the Penal Code, the minimum of the penalty of imprisonment is 1 month.

The punishability of the offence criminalized by Article 264, paragraph 2 of the Penal Code ceases after the expiration of 5 years from the time the offence was committed (Article 101, paragraph 1, point 4) and of the offence criminalized by Article 264, paragraph 3 - after 15 years (Article 101, paragraph 1, point 2a). However, if criminal proceedings against the offender have been commenced in the period provided for in Article 101, the offence falls under the statute of limitations after a lapse of 5 years from the end of that period (Article 102 of the Penal Code). In other words, the period of the punishability of the offence is prolonged by 5 years.

34 Compare Ćwiąkalski, "Komentarz do art. 264 k.k.," 1449.

35 Wiak, "Komentarz do art. 264 k.k.," 1223; Herzog, "Komentarz do art. 264 k. k.," 1658; Jachimowicz, "Nowe zasady odpowiedzialności za nielegalne przekroczenie granicy RP," 51; Joanna PiórkowskaFlieger, "Komentarz do art. 264 k.k.," in Kodeks karny. Komentarz, ed. T. Bojarski (Warszawa: Lexis Nexis, 2011), 628; Gruszecka, "Komentarz do art. 264 k.k.," 965; Kalitowski, “Komentarz do art. 264 k.k.," 1385; Michalska-Warias, “Komentarz do art. 264 k.k.," 398-99; Ćwiąkalski, "Komentarz do art. 264 k.k.," 1452; Marek Mozgawa, "Komentarz do art. 264 k.k.," in Kodeks karny. Komentarz, ed. M. Mozgawa (Warszawa: LEX a Wolters Kluwer business, 2014), 658. 
The rehabilitation of an offender sentenced to the punishment provided for in Article 264 is regulated by Article 107 of the Penal Code. According to Article 107, paragraph 1, the conviction becomes spent by virtue of law after the expiration of 10 years from the execution or remission of the imposed penalty or from the time the execution of the imposed penalty is barred by the statute of limitations. However, if the imposed penalty did not exceed 3 years, on a motion of the sentenced person, the court may order that the conviction becomes spent after the expiration of 5 years, if the sentenced person has respected the legal order during this period (Article 107, paragraph 2 of the Penal Code).

With the aim of making an evaluation of Polish criminal law regulations, Article 4, paragraph 3 of the Schengen Borders Code should be reminded. According to this provision, the Member States shall introduce effective, proportionate and dissuasive penalties for the unauthorized crossing of external borders at places other than border crossing points or at times other than the fixed opening hours. The above-made analysis of the three relevant offences allows to state that the penalties provided for in Polish law are proportionate, effective, and dissuasive. Thus, Polish lawmakers fulfilled the international obligation in this aspect. The general and final conclusion is that the current Polish criminal law regulations on the illegal crossing of the state border are rational and do not need to be changed.

\section{Bibliography}

\section{Legal Acts}

Agreement between the Republic of Poland and Ukraine "On Legal Regime on the PolishUkrainian State Border and Cooperation and Mutual Assistance in Border Issues." Kyiv, January 12, 1993, Dziennik Ustaw 63 (1994), item 267.

Announcement of the Interior Minister of 3 July 2015 "On the Border Crossing points, Type of Movement Allowed at these Crossing Points and Opening Hours of these Crossing Points." Monitor Polski, July 21, 2015, item 636. Accessed March 18, 2016, http://isip.sejm.gov.pl/ DetailsServlet?id=WMP201500oo636.

"Council Regulation (EC) No 539/2001 of 15 March 2001 Listing the Third Countries whose Nationals Must be in Possession of Visas when Crossing the External Borders and those whose Nationals are Exempt from that Requirement." Accessed March 16, 2016. http://eurlex.europa.eu/legal-content/EN/ALL/?uri=celex\%3A32001Ro539.

"Regulation No 562/2006 of the European Parliament and of the Council of 15 March 2006 Establishing a Community Code on the Rules Governing the Movement of Persons across Borders (Schengen Borders Code)." Accessed March 15, 2016. http://eur-lex.europa.eu/ legal-content/EN/TXT/?uri=URISERV\%3Al14514.

Statute of 12 October 1990 "On the Border Guard." Dziennik Ustaw, November 19, 199o, No. 78, item 462 , with later changes.

Statute of 12 October 1990 "On the Protection of State Border." Dziennik Ustaw, November 19, 1990, No. 78 , pos. 461 with later changes. 
Statute of 2 April 1997 "The Constitution of the Republic of Poland." Dziennik Ustaw, July 16, 1997 , No. 78 , item 483, with later changes.

Statute of 20 May 1971 "The Code of Contraventions." Dziennik Ustaw, May 31, 1971, No. 12, item 114, with later changes.

Statute of 6 June 1997 "The Penal Code." Dziennik Ustaw, August 2, 1997, No. 88, item 553, with later changes.

\section{Literature}

Bojarski, Marek. "Komentarz do art. 49a k.w." In Kodeks wykroczeń. Komentarz, edited by M. Bojarski and W. Radecki, 394-98. Warszawa: C. H. Beck, 2013.

Bojarski, Tadeusz. "Komentarz do art. 49a k.w." In Kodeks wykroczeń. Komentarz, edited by T. Bojarski, 119-20. Warszawa: Lexis Nexis, 2009.

Ćwiąkalski, Zbigniew. "Komentarz do art. 264 k.k." In Kodeks karny. Część szczególna. Tom II. Komentarz do art. 117-277, edited by A. Zoll, 1446-53. Warszawa: LEX a Wolters Kluwer business, 2013 .

Góral, Roman. Kodeks karny. Praktyczny komentarz. Warszawa: Wydawnictwo Zrzeszenia Prawników Polskich, 2007.

Gruszecka, Dagmara. “Komentarz do art. 264 k.k." In Kodeks karny. Część szczególna. Komentarz, edited by J. Giezek, 96o-5. Warszawa: LEX a Wolters Kluwer business, 2014.

Herzog, Aleksander. "Komentarz do art. 264 k.k." In Kodeks karny. Komentarz, edited by R. A. Stefański, 1656-59. Warszawa: C. H. Beck, 2015.

Jachimowicz, Marcin. "Nowe zasady odpowiedzialności za nielegalne przekroczenie granicy RP." Prokuratura i Prawo 5 (2006): 49-64.

Kalitowski, Michał. “Komentarz do art. 264 k.k.” In Kodeks karny. Komentarz, edited by M. Filar, 1383-85. Warszawa: Wolters Kluwer, 2014.

Kotowski, Wojciech. Kodeks wykroczeń. Komentarz. Warszawa: Oficyna a Wolters Kluwer business, 2009 .

Marek, Andrzej. Kodeks karny. Komentarz. Warszawa: LEX a Wolters Kluwer business, 2010.

Marek, Andrzej. Prawo karne. Warszawa: C. H. Beck, 2011.

Michalska-Warias, Aneta. "Komentarz do art. 264 k.k." In Kodeks karny. Część szczególna. Tom II. Komentarz. Art. 222-316, edited by M. Królikowski and R. Zabłocki, 392-402. Warszawa: C. H. Beck, 2013 .

Mirgos, Zbigniew. "Przestępstwo bezprawnego przekroczenia granicy państwowej PRL na tle porównawczym." Nowe Prawo 9 (1987): 43-57.

Mozgawa, Marek. "Komentarz do art. 264 k.k." In Kodeks karny. Komentarz, edited by M. Mozgawa, 655-58. Warszawa: LEX a Wolters Kluwer business, 2014.

Mozgawa, Marek. "Komentarz do art. 49a k.w." In Kodeks wykroczeń. Komentarz, edited by M. Mozgawa, 175-77. Warszawa: LEX a Wolters Kluwer business, 2009.

Piórkowska-Flieger, Joanna. "Komentarz do art. 264 k.k." In Kodeks karny. Komentarz, edited by T. Bojarski, 626-28. Warszawa: Lexis Nexis, 2011.

Wiak, Krzysztof. "Komentarz do art. 264 k.k." In Kodeks karny. Komentarz, edited by A. Grześkowiak and K. Wiak, 1223-25. Warszawa: C. H. Beck, 2015. 


\section{Electronic Sources}

“Granice RP.” The Border Guard website. April 23, 2008. Accessed March 19, 2016. https://www. strazgraniczna.pl/pl/granica/granice-rp/1910, Granice-RP.html.

"Polska w strefie Schengen." The Embassy of the Republic of Poland in Cairo website. Accessed December 17, 2016. http://www.kair.msz.gov.pl/pl/informacje_konsularne/polska_w_ schengen $/$.

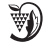

Katarzyna Banasik is an Associate Professor at Andrzej Frycz Modrzewski Krakow University (Krakow, Poland). She was granted the degree of Habilitated Doctor of Laws from Jagiellonian University (Krakow, Poland). She specializes in criminal law. She is the author of many publications, mainly on substantive criminal law. Her research interests include criminal law, international law, criminal procedure, criminal enforcement law, and the law of contraventions. She also carried out comparative research work focusing on German, Austrian, and English law. 